\title{
Green and High Efficient Synthesis of 2-Aryl Benzimidazoles: Reaction of Arylidene Malononitrile and 1,2-Phenylenediamine Derivatives in Water or Solvent-Free Conditions
}

\author{
Azizollah Habibi1 ${ }^{*}$, Yousef Valizadeh1, Marjan Mollazadeh², Abdolali Alizadeh ${ }^{3}$ \\ ${ }^{1}$ Faculty of Chemistry, Kharazmi University, Tehran, Iran \\ ${ }^{2}$ School of Chemistry, College of Science, University of Tehran, Tehran, Iran \\ ${ }^{3}$ Department of Chemistry, Tarbiat Modares University, Tehran, Iran \\ Email: "habibi@khu.ac.ir
}

Received 20 August 2015; accepted 6 December 2015; published 9 December 2015

Copyright (C) 2015 by authors and Scientific Research Publishing Inc.

This work is licensed under the Creative Commons Attribution International License (CC BY). http://creativecommons.org/licenses/by/4.0/

\section{(c) (i) Open Access}

\begin{abstract}
A fast, high efficiency and environmentally friendly procedure for the synthesis of 2-aryl benzimidazole derivatives has been reported. Reaction between 1,2-phenylenediamine derivatives and arylidene malononitrile under aqueous media and also solvent-free conditions generates 2-aryl benzimidazole derivatives with a high yield.
\end{abstract}

Keywords

Benzimidazoles, Green Chemistry, Arylidene Malononitrile, 1,2-Phenylenediamines

\section{Introduction}

In recent years, significant attentions have been considered to the organic reaction under aqueous media, particularly from the viewpoint of green chemistry [1]-[4]. Using water, in contrast to common hazardous organic solvents, offers many advantages such as: simplicity of reaction conditions, ease of work-up and product isolation, increasing the selectivity of a wide variety of organic reactions and accelerating reaction rates [5] [6]. Ben-

\footnotetext{
${ }^{*}$ Corresponding author.
}

How to cite this paper: Habibi, A., Valizadeh, Y., Mollazadeh, M. and Alizadeh, A. (2015) Green and High Efficient Synthesis of 2-Aryl Benzimidazoles: Reaction of Arylidene Malononitrile and 1,2-Phenylenediamine Derivatives in Water or SolventFree Conditions. International Journal of Organic Chemistry, 5, 256-263. http://dx.doi.org/10.4236/ijoc.2015.54025 
zimidazole derivatives are important scaffolds in medicinal chemistry due to their biological and pharmacological activities. These compounds exhibit activity against several viruses include HIV [7] [8], influenza [9], herpes (HSV-1) [10], RNA [11] and human cytomegalovirus (HCMV) [12]. They have also been employed as antihypertensive, antiviral, anticancer, antiulcer, antifungal and untihistamine [13]-[18].

In view of the biological importance of benzimidazoles, there have been growing interests in the development of efficient, fast, simple and environment friendly synthetic methods for the preparation of these molecules. Several procedures have been reported for the synthesis of 2-substituted benzimidazoles: Condensation of 1,2phenylenediamines with carboxylic acids, acid chlorides, nitriles, imidates and orthoesters under strong acidic conditions, sometimes combined with very high temperatures or useing microwave irradiation, [19]-[22] oxidative cyclodehydrogenation of 1,2-phenylenediamine and aldehydes in the presence of different oxidants [23][26], transition-metal-catalyzed intramolecular cyclization of 2-haloanilides and their analogues [27]-[29] and also the condensation reactions of 1,2-phenylenediamine with $\beta$-ketonitriles [30], $\beta$-ketoesters [31] [32], or $\beta$ diketones [33] under microwave radiation and high temperature conditions or in the presence of a catalyst. Although, all of these methods are widely employed, but they have drawbacks such as low yields, the use of expensive and toxic reagents, catalysts and solvents, long reaction times, formation of side-products, tedious work-up procedure, and in some cases, harsh reaction conditions are required. Therefore, development of efficient, economical, and environmentally benign synthetic protocols for their construction is an important goal in diverse areas of chemistry. In addition, a number of other useful green reactions for the synthesis of benzimidazole derivatives have been reported in the literature. For example, Su and co-workers reported synthesis of substituted benzimidazoles from 1,2-phenylenediamine and arylaldehydes or arylmethylenemalononitriles absorbed on silica gel by intermittent grinding or by a microwave-assisted technique under solvent- and catalyst-free conditions [34]. Also, Chikashita and co-workers described formation of 2-aryl benzmidazoles with reaction between of arylidenemalononitriles or $\beta$-nitrostyrenes with 1,2-phenylenediamine in ethanol at boiling temperature through a simple and efficient transfer-hydrogenation process from the in situ generated benzimidazolines to activate olfines [35].

In order to further development of synthetic route of benzimidazoles under green reaction conditions, here, we devoted our effort for the synthesis of 2-aryl benzimidazole derivatives in water as a green solvent as well as solvent-free conditions (Scheme 1).

\section{Result and Discussion}

In this work, we report a highly efficient, and environmentally benign procedure for the reaction of 1,2-phenylenediamine derivatives $\mathbf{1}$ with arylidenemalononitrile $\mathbf{2}$ in aqueous medium as a green solvent to produce benzimidazole derivatives $\mathbf{3}$. Also, in continuation of our goal towards performing of this reaction under another green condition, we have developed reaction between reactants under solvent-free condition using thermal heating method after grinding. Arylidenemalononitrile 2 was reacted with 1,2-phenylenediamine derivatives in the presence of water to produce the related products 3 with excellent yields. We initially employed 1,2-phenylnediamine $1 \mathbf{a}(1 \mathrm{mmol})$ and arylidenemalononitrile $\mathbf{2 a}(2 \mathrm{mmol})$ in water at room temperature as a model reaction. In this condition the reaction wasn't complete after 14 hours (Table 1, entry 1). Therefore, various conditions have been designed to determine the optimized conditions. Different solvents such as water, ethanol, methanol, acetone, dimethylsuloxide, tetrahydrofuran, and chloroform were explored. Also, the reaction was performed under different temperatures such as $25^{\circ} \mathrm{C}, 50^{\circ} \mathrm{C}, 75^{\circ} \mathrm{C}$ and $90^{\circ} \mathrm{C}$. The results are summarized in Table 1. As can be seen, the best result was obtained by the reaction mixture in water at $75^{\circ} \mathrm{C}$ for $20 \mathrm{~min}$ to yield product

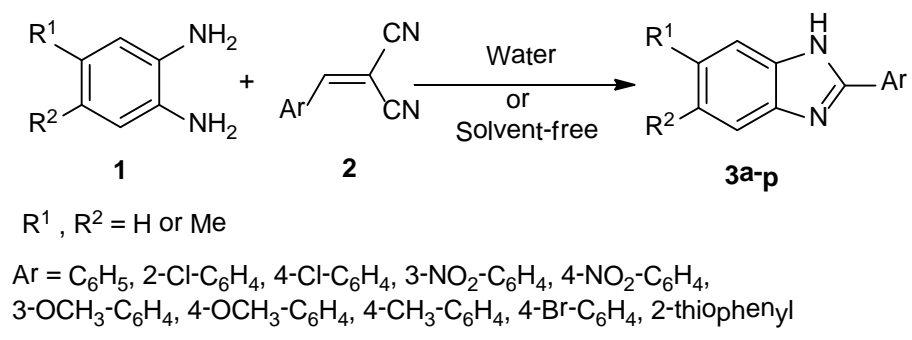

Scheme 1. Synthesis of 2-aryl benzimidazole derivatives. 
Table 1. Effect of different reaction conditions for synthesis of product $\mathbf{3} \mathbf{a}^{\mathrm{a}}$.

\begin{tabular}{|c|c|c|c|c|}
\hline Entry & Solvent & Tem. $\left[{ }^{\circ} \mathrm{C}\right]$ & Time [min] & Yield [\%] \\
\hline 1 & $\mathrm{H}_{2} \mathrm{O}$ & 25 & $14 \mathrm{~h}$ & $40^{c}$ \\
\hline 2 & $\mathrm{H}_{2} \mathrm{O}$ & 50 & 5 & 75 \\
\hline 3 & $\mathrm{H}_{2} \mathrm{O}$ & 50 & 10 & 79 \\
\hline 4 & $\mathrm{H}_{2} \mathrm{O}$ & 50 & 15 & 83 \\
\hline 5 & $\mathrm{H}_{2} \mathrm{O}$ & 50 & 20 & 83 \\
\hline 6 & $\mathrm{H}_{2} \mathrm{O}$ & 75 & 5 & 80 \\
\hline 7 & $\mathrm{H}_{2} \mathrm{O}$ & 75 & 10 & 86 \\
\hline 8 & $\mathrm{H}_{2} \mathrm{O}$ & 75 & 15 & 89 \\
\hline 9 & $\mathrm{H}_{2} \mathrm{O}$ & 75 & 20 & 92 \\
\hline 10 & $\mathrm{H}_{2} \mathrm{O}$ & 75 & 30 & 92 \\
\hline 11 & $\mathrm{H}_{2} \mathrm{O}$ & 90 & 10 & 88 \\
\hline 12 & $\mathrm{H}_{2} \mathrm{O}$ & 90 & 20 & 90 \\
\hline 13 & $\mathrm{H}_{2} \mathrm{O}$ & 90 & 30 & 90 \\
\hline 14 & $\mathrm{EtOH}$ & reflux & 20 & 91 \\
\hline 15 & $\mathrm{MeOH}$ & reflux & 20 & 89 \\
\hline 16 & Acetone & reflux & 20 & 70 \\
\hline 17 & DMSO & 50 & 20 & 85 \\
\hline 18 & THF & 50 & 20 & 77 \\
\hline 19 & $\mathrm{CHCl}_{3}$ & reflux & 20 & 65 \\
\hline 20 & No solvent & 75 & 20 & 79 \\
\hline 21 & No solvent & 90 & 20 & 82 \\
\hline 22 & No solvent & 90 & 30 & 87 \\
\hline
\end{tabular}

${ }^{\mathrm{a}}$ Reaction condition: 1,2-phenylenediamine $\mathbf{1 a}$ (1 mmol) and arylidenemalononitrile 2a (2 mmol); ${ }^{\mathrm{b}}$ Isolated yield. ' $y i e l d$ based on TLC analysis.

3a (Table 1, entry 9). Although, the reaction gave high to excellent yields in organic solvents, but using water is the most advantageous to this method (Table 1, entries 14 - 19). After optimizing the reaction condition, to explore the scope and generality, the synthesis of benzimidazole derivatives 3a-p were carried out through the reaction of 1,2-phenylenediamine derivatives and a wide diversity of arylidenemalononitrile in high yields (Table 2). Interestingly, we observed that the position and nature of substitution on the ring of arylidenemalononitrile did not make much difference in reactivity, indicating the wide scope of this methodology.

In continuation of this study, we are interested in solvent-free conditions as another green procedure by using grinding method. Thus, we have synthesized a series of 2-substituted benzimidazoles 3a-p by the reaction of reactants under this method on heating. Therefore, the reaction of arylidenemalononitrile 2a and 1,2-phenylnediamine 1a proceeded successfully in an open vial through grinding of two components together and then heating at $90^{\circ} \mathrm{C}$ for $30 \mathrm{~min}$. This reaction started immediately after heating, with liquification of the mixture, followed by solidification of the mixture of reaction. By comparing the reaction time and yields of entries 20 to 22 in Table 1, it was found that $30 \mathrm{~min}$ and $90^{\circ} \mathrm{C}$ was best conditions for this reaction. Also, it was found that both 
Table 2. Synthesis of 2-aryl benzimidazoles 3a-p.

\begin{tabular}{|c|c|c|c|c|c|c|c|}
\hline \multirow{2}{*}{ Compound } & \multirow{2}{*}{$\mathrm{Ar}$} & \multirow{2}{*}{$\mathrm{R}^{1}$} & \multirow{2}{*}{$\mathrm{R}^{2}$} & \multirow{2}{*}{ M.p. (lit. m. p.) $/\left[{ }^{\circ} \mathrm{C}\right]$} & $\mathrm{H}_{2} \mathrm{O}^{\mathrm{a}}$ & Solvent-free $^{\mathrm{b}}$ & \multirow{2}{*}{ Ref } \\
\hline & & & & & Yield [\%] $^{\mathrm{c}}$ & Yield [\%] $^{c}$ & \\
\hline 3a & $\mathrm{C}_{6} \mathrm{H}_{5}$ & $\mathrm{H}$ & $\mathrm{H}$ & 287-289 (288-290) & 92 & 87 & {$[36]$} \\
\hline $3 \mathbf{b}$ & 2-Cl- $\mathrm{C}_{6} \mathrm{H}_{4}$ & $\mathrm{H}$ & $\mathrm{H}$ & 231-233 (233-234) & 86 & 87 & [41] \\
\hline $3 c$ & $4-\mathrm{Cl}-\mathrm{C}_{6} \mathrm{H}_{4}$ & $\mathrm{H}$ & $\mathrm{H}$ & 291-293 (287-289) & 89 & 88 & [37] \\
\hline 3d & $3-\mathrm{NO}_{2}-\mathrm{C}_{6} \mathrm{H}_{4}$ & $\mathrm{H}$ & $\mathrm{H}$ & 204-207 (205) & 88 & 87 & [38] \\
\hline $3 \mathbf{e}$ & $4-\mathrm{NO}_{2}-\mathrm{C}_{6} \mathrm{H}_{4}$ & $\mathrm{H}$ & $\mathrm{H}$ & 325-327 (328) & 90 & 91 & [40] \\
\hline $3 f$ & $3-\mathrm{MeO}-\mathrm{C}_{6} \mathrm{H}_{4}$ & $\mathrm{H}$ & $\mathrm{H}$ & 202-205 (201-204) & 86 & 83 & {$[41]$} \\
\hline $3 g$ & 4-MeO- $\mathrm{C}_{6} \mathrm{H}_{4}$ & $\mathrm{H}$ & $\mathrm{H}$ & $223-226$ (225) & 93 & 90 & [38] \\
\hline $3 h$ & 4-Me- $\mathrm{C}_{6} \mathrm{H}_{4}$ & $\mathrm{H}$ & $\mathrm{H}$ & $275-276(278)$ & 92 & 90 & [38] \\
\hline $3 \mathbf{i}$ & $4-\mathrm{Br}-\mathrm{C}_{6} \mathrm{H}_{4}$ & $\mathrm{H}$ & $\mathrm{H}$ & 299-300 (298) & 85 & 87 & [40] \\
\hline $3 \mathbf{j}$ & $2-\mathrm{C}_{4} \mathrm{H}_{4} \mathrm{~S}$ & $\mathrm{H}$ & $\mathrm{H}$ & 330-333 (330) & 90 & 88 & {$[40]$} \\
\hline $3 \mathbf{k}$ & $\mathrm{C}_{6} \mathrm{H}_{5}$ & $\mathrm{Me}$ & $\mathrm{H}$ & $240-242(241-242)$ & 93 & 91 & [36] \\
\hline 31 & 2-Cl- $\mathrm{C}_{6} \mathrm{H}_{4}$ & $\mathrm{Me}$ & $\mathrm{H}$ & 104-106 (106-108) & 87 & 88 & {$[36]$} \\
\hline $3 m$ & $4-\mathrm{Cl}-\mathrm{C}_{6} \mathrm{H}_{4}$ & $\mathrm{Me}$ & $\mathrm{H}$ & $225-227(224)$ & 90 & 89 & {$[42]$} \\
\hline $3 n$ & $\mathrm{C}_{6} \mathrm{H}_{5}$ & $\mathrm{Me}$ & $\mathrm{Me}$ & 251-252 (244-247) & 85 & 87 & [39] \\
\hline 30 & $2-\mathrm{C}_{4} \mathrm{H}_{4} \mathrm{~S}$ & $\mathrm{Me}$ & $\mathrm{Me}$ & $240-242$ & 93 & 91 & {$[43]$} \\
\hline $3 \mathbf{p}$ & $3-\mathrm{MeO}-\mathrm{C}_{6} \mathrm{H}_{4}$ & $\mathrm{Me}$ & $\mathrm{Me}$ & $240-243$ & 93 & 90 & {$[43]$} \\
\hline
\end{tabular}

${ }^{\mathrm{a}}$ Reaction condition: 1,2-phenylenediamine derivatives 1 (1 mmol), arylidene malononitrile 2 (2 mmol), water (5 ml) under $75^{\circ} \mathrm{C}$ and $20 \mathrm{~min} ;{ }^{\mathrm{b}} \mathrm{Reac}-$ tion condition: 1,2-phenylenediamine derivatives $1(1 \mathrm{mmol})$, arylidene malononitrile $2(2 \mathrm{mmol})$, grinding heating at $90^{\circ} \mathrm{C}$ for $30 \mathrm{~min}$; ${ }^{\circ} \mathrm{Isolated}$ yield.

electron-donating and electron-deficient groups were suitable for this reaction because the products were obtained in excellent yields. In addition, a heterocyclic arylidenemalononitrile such as 2-(thiophen-2-ylmethylene) malononitrile could react with 1,2-phenylenediamine and 4,5-dimethyl-1,2-phenylenediamine to afford the corresponding benzimidazole (Table 2). The known compounds were identified by comparison of their melting point with those reported earlier (see references in Table 2). Also, a number of these compounds was characterized by its ${ }^{1} \mathrm{H}-\mathrm{NMR}$. A plausible mechanism based on reported previous work [35] is proposed in Scheme 2. Initially, Michael addition reaction of 1,2-phenylenediamine $\mathbf{1}$ with the arilydenemalononitrile $\mathbf{2}$ gave intermediate $\mathbf{4}$. The consequent proton transfer results transformation of $\mathbf{4}$ into $\mathbf{5}$. Then this intermediate converted to benzimidazoline $\mathbf{7}$ with leave malononitrile as leaving group perhaps by one of two paths (path $\mathbf{a}$ or $\mathbf{b}$ ). The benzimidazole 3 is formed through a simple and efficient transfer-hydrogenation process from in situ generated benzimidazoline to arylidenemalononitrile.

\section{Conclusion}

In summary, we have reported green and highly efficient method for the synthesis of 2-aryl benzimidazoles in water as well as under solvent-free and catalyst-free conditions. The main advantages of these procedures are environmentally friendly, the operational simplicity, short reaction times, simple work-up procedures and high yields. 

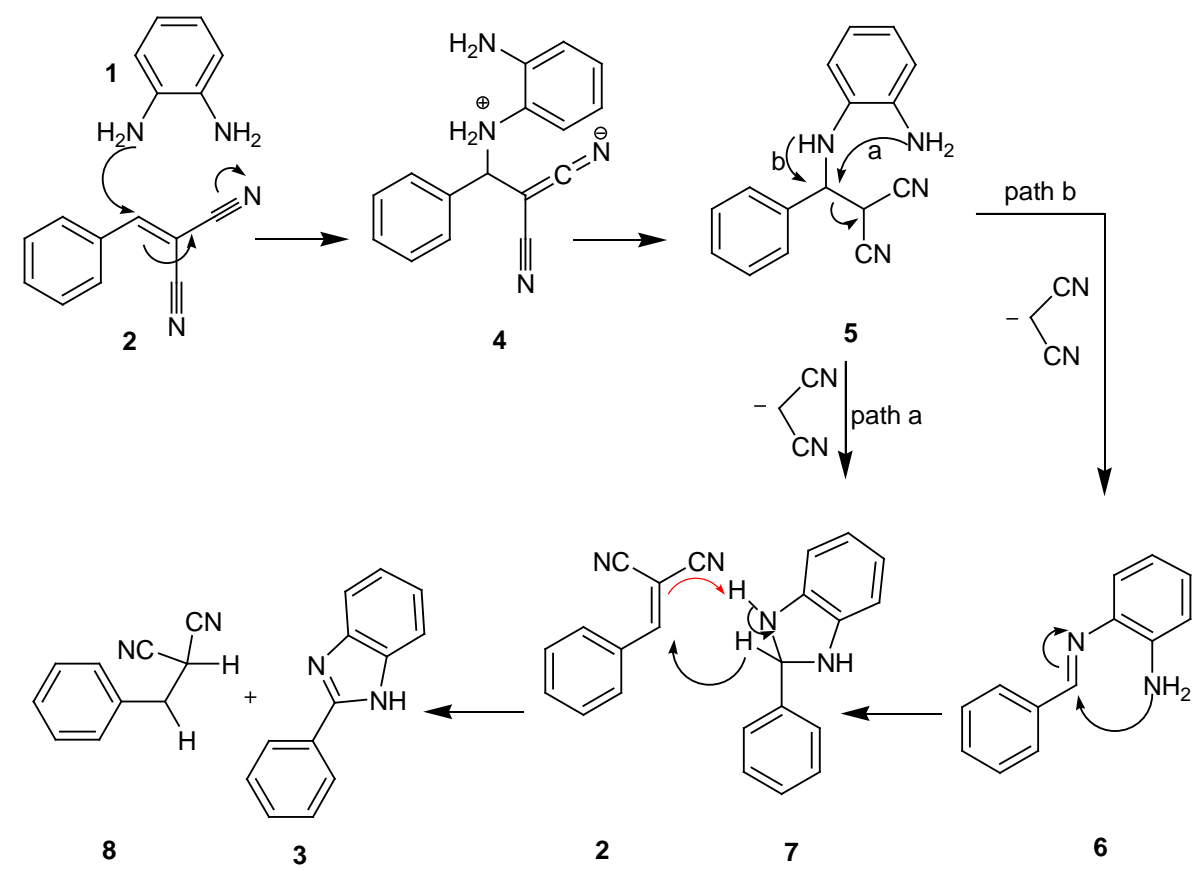

Scheme 2. Plausible mechanism for the formation of products 3a-p.

\section{Experimental}

1,2-phenylenediamine derivatives, malononitrile and aldehyde derivatives were purchased from the Merck and Fulka companies and were used without further purification. Melting points were determined on Electrothermal 9100 apparatus. ${ }^{1} \mathrm{H}$ NMR spectra was recorded on a Bruker Avance $300 \mathrm{MHz}$ employing tetramethylsilane as an internal standard.

\subsection{General Procedure for the Synthesis of 2-Aryl Benzimidazole 3a-p in Water}

1,2-phenylenediamine $(1 \mathrm{mmol})$ was dissolved in $5 \mathrm{ml}$ water at $75^{\circ} \mathrm{C}$. Then, arylidenemalononitrile $(2 \mathrm{mmol})$ was added to this solution, and immediately the reaction mixture liquefied and resolidified. The reaction was monitored by TLC (petroleum ether: Ethyl Acetate (8:2)) till the disappearance of the starting arylidene malononitrile. After cooling the resultant reaction mixture, recrystalization in ethanol-water and finally pure 2-aryl bezimidazole was filtered out.

\subsection{General Procedure for the Synthesis of 2-Aryl Benzimidazole 3a-p in Solvent-Free Conditions Using Conventional Heating Method}

Arylidenemalononitrile (2 mmol) and 1,2-phenylenediamine (1 mmol) were mixed thoroughly with glass stirrer and heated at $90^{\circ} \mathrm{C}$. The reaction mixture liquefied and resolidified in $30 \mathrm{~min}$. Completion of the reaction was checked by TLC (petroleum ether: Ethyl Acetate (8:2)). After cooling the resultant semi-solid reaction mixture, crystallization was performed in ethanol-water and 2-aryl bezimidazole was filtered out.

2-Phenylbenzimidazole [36]: m.p. $=287^{\circ} \mathrm{C}-289^{\circ} \mathrm{C},{ }^{1} \mathrm{H}$ NMR $\left(300 \mathrm{MHz}\right.$, DMSO- $\left.d_{6}\right): \delta=7.19-7.25(\mathrm{~m}, 2 \mathrm{H}$, ArH), $7.48-7.54(\mathrm{~m}, 1 \mathrm{H}, \mathrm{ArH}), 7.62$ (d, $J=8.6 \mathrm{~Hz}, 2 \mathrm{H}, \mathrm{ArH}), 7.67-7.73(\mathrm{~m}, 2 \mathrm{H}, \mathrm{ArH}), 8.17$ (d, $J=8.6 \mathrm{~Hz}, 2 \mathrm{H}$, ArH), 8.54 (s, 1H, NH).

2-(2-Cholorophenyl) benzimidazole [41]: m.p. $=231^{\circ} \mathrm{C}-233^{\circ} \mathrm{C} .{ }^{1} \mathrm{H}$ NMR $\left(300 \mathrm{MHz}\right.$, DMSO- $\left.d_{6}\right): \delta=7.26$ 7.36 (m, 2H, ArH), 7.38 - 7.44 (m, 2H, ArH), 7.48 - 7.51 (m, 1H, ArH), 7.69 (m, 2H, ArH), 8.41 (m, 1H, ArH), 10.36 (br s, $1 \mathrm{H}, \mathrm{NH}$ ).

2-(4-Chlorophenyl) benzimidazole [37]: m.p. $=291^{\circ} \mathrm{C}-93^{\circ} \mathrm{C},{ }^{1} \mathrm{H}$ NMR $\left(300 \mathrm{MHz}, \mathrm{CDCl}_{3}\right): \delta=7.29-7.32$ (m, 1H, ArH), 7.49 - 7.54 (m, 3H, ArH), 7.73 - 7.88 (m, 3H, ArH), 7.98 - 8.00 (m, 1H, ArH), 9.3 (br s, 1H, NH).

2-(3-Nitrophenyl) benzimidazole [38]: m.p. $=204^{\circ} \mathrm{C}-207^{\circ} \mathrm{C},{ }^{1} \mathrm{H}$ NMR $\left(300 \mathrm{MHz}\right.$, DMSO- $\left.d_{6}\right): \delta=7.20-$ 
7.30 (m, 2H, ArH), 7.57 (d, $J=7.3 \mathrm{~Hz}, 1 \mathrm{H}, \mathrm{ArH}), 7.71$ (d, $J=7.8 \mathrm{~Hz}, 1 \mathrm{H}, \mathrm{ArH}), 7.85$ (dd, $J_{1}=7.9 \mathrm{~Hz}, J_{2}=7.9$ $\mathrm{Hz}, 1 \mathrm{H}, \mathrm{ArH}), 8.32$ (dd, $\left.J_{1}=2.0 \mathrm{~Hz}, J_{2}=7.9 \mathrm{~Hz}, 1 \mathrm{H}, \mathrm{ArH}\right), 8.61(\mathrm{~d}, J=7.9 \mathrm{~Hz}, 1 \mathrm{H}, \mathrm{ArH}), 9.01$ (dd, $J=2.0 \mathrm{~Hz}$, $J=2.0 \mathrm{~Hz}, 1 \mathrm{H}, \mathrm{ArH}), 13.30$ (s, $1 \mathrm{H}, \mathrm{NH}$ ).

2-(3-Methoxyphenyl) benzimidazole [41]: m.p. $=202^{\circ} \mathrm{C}-205^{\circ} \mathrm{C},{ }^{1} \mathrm{H}$ NMR $\left(300 \mathrm{MHz}\right.$, DMSO- $\left.d_{6}\right): \delta=3.84$ (s, 3H, OMe), 6.95 (d, $J=8.6 \mathrm{~Hz}, 2 \mathrm{H}, \mathrm{ArH}), 7.00-7.92$ (m, 4H, ArH), 8.03 (d, $J=8.6 \mathrm{~Hz}, 2 \mathrm{H}, \mathrm{ArH}$ ).

2-(4-Methoxyphenyl) benzimidazole [38]: m.p. $=223^{\circ} \mathrm{C}-226^{\circ} \mathrm{C},{ }^{1} \mathrm{H}$ NMR $\left(300 \mathrm{MHz}\right.$, DMSO- $\left.d_{6}\right): \delta=3.83$ (s, $3 \mathrm{H}, \mathrm{OMe}$ ), 6.95 (d, $J=8.8 \mathrm{~Hz}, 2 \mathrm{H}, \mathrm{ArH}$ ), 7.23 (dd, $J_{1}=3.2 \mathrm{~Hz}, J_{2}=6.0 \mathrm{~Hz}, 2 \mathrm{H}, \mathrm{ArH}$ ), 7.60 (dd, $J_{1}=3.2 \mathrm{~Hz}$, $\left.J_{2}=6.0 \mathrm{~Hz}, 2 \mathrm{H}, \mathrm{ArH}\right), 8.04(\mathrm{~d}, J=8.8 \mathrm{~Hz}, 2 \mathrm{H}, \mathrm{ArH})$.

2-(Thiophen-2-yl) benzoimidazole $[40]:$ m.p. $=330^{\circ} \mathrm{C}-333^{\circ} \mathrm{C},{ }^{1} \mathrm{H}$ NMR $\left(300 \mathrm{MHz}, \mathrm{CDCl}_{3}\right): \delta=7.15-7.18$ (m, 1H, ArH), 7.27 - 7.29 (m, 2H, ArH), 7.47 - 7.49 (m, 2H, ArH), 7.61 - 7.62 (m, 1H, ArH), 7.80 - 7.81 (m, 1H, ArH).

5,6-Dimethyl-2-phenylbenzoimidazole [43]: m.p. $=251^{\circ} \mathrm{C}-252^{\circ} \mathrm{C},{ }^{1} \mathrm{H}$ NMR $\left(300 \mathrm{MHz}, \mathrm{DMSO}-\mathrm{d}_{6}\right): \delta=$ 2.31 (s, 6H, 2Me), $7.34-7.54$ (m, 4H, ArH), 8.12 (d, $J=8.0 \mathrm{~Hz}, 2 \mathrm{H}, \mathrm{ArH}), 12.69$ (br s, $1 \mathrm{H}, \mathrm{NH}$ ).

2-(3-Methoxyphenyl)-5,6-dimethylbenzoimidazole [43]: m.p. $=240{ }^{\circ} \mathrm{C}-243^{\circ} \mathrm{C} .{ }^{1} \mathrm{H}$ NMR $(300 \mathrm{MHz}$, DMSO- $d_{6}$ ): $\delta=2.31$ (s, 6H, 2Me), 3.84 (s, 3H, OMe), 6.99 - 7.03 (m, 2H, ArH), 7.30 - 7.45 (m, 2H, ArH), 7.69 - 7.72 (m, 2H, ArH), 12.60 (1, br s, NH).

\section{References}

[1] Lindstrom, U.M. (2007) Organic Reactions in Water: Principles Strategies and Applications. Blackwell, Oxford. http://dx.doi.org/10.1002/9780470988817

[2] Lindstrom, U.M. (2002) Stereoselective Organic Reactions in Water. Chemical Reviews, 102, 2751-2772. http://dx.doi.org/10.1021/cr010122p

[3] Shapiro. N. and Vigalok. A. (2008) Highly Efficient Organic Reactions “on Water”, “in Water”, and Both. Angewandte Chemie, 120, 2891-2894. http://dx.doi.org/10.1002/ange.200705347

[4] Li, C.-J. (2005) Organic Reactions in Aqueous Media with a Focus on Carbon-Carbon Bond Formations: A Decade Update. Chemical Reviews, 105, 3095-3166. http://dx.doi.org/10.1021/cr030009u

[5] Grieco, P.A. (1998) Organic Synthesis in Water. Blackie Academic \& Professional, London. http://dx.doi.org/10.1007/978-94-011-4950-1

[6] Li, C.-J. and Chan, T.-H. (2007) Comprehensive Organic Reactions in Aqueous Media. Wiley \& Sons, New York. http://dx.doi.org/10.1002/9780470131442

[7] Rida, S.M.S., EI-Hawash, A.M., Fahmy, H.T.Y., Hazzaa, A.A. and EI-Meligy, M.M.M. (2006) Synthesis of Novel Benzofuran and Related Benzimidazole Derivatives for Evaluation of in Vitro Anti-HIV-1, Anticancer and Antimicrobial Activities. Archives of Pharmacal Research, 29, 826-833. http://dx.doi.org/10.1007/BF02973901

[8] Roth, T., Morningstar, M.L., Boyer, P.L., Hughes, S.H., Buckheitjr, R.W. and Michejda, C.J. (1997) Synthesis and Biological Activity of Novel Nonnucleoside Inhibitors of HIV-1 Reverse Transcriptase. 2-Aryl-Substituted Benzimidazoles. Journal of Medicinal Chemistry, 40, 4199-4207. http://dx.doi.org/10.1021/jm970096g

[9] Hisano, T., Ichikawa, M., Tsumoto, K. and Tasaki, M. (1982) Synthesis of Benzoxazoles, Benzothiazoles and Benzimidazoles and Evaluation of Their Antifungal, Insecticidal and Herbicidal Activities. Chemical and Pharmaceutical Bulletin, 30, 2996-3004. http://dx.doi.org/10.1248/cpb.30.2996

[10] Migawa, M.T., Girardet, J.-L., Walker, J.A., Koszalka, G.W., Chamberlain, S.D., Drach, J.C. and Townsend, L.B. (1998) Design, Synthesis, and Antiviral Activity of $\alpha$-Nucleosides: $d$ - and l-Isomers of Lyxofuranosyl- and (5-Deoxylyxofuranosyl)benzimidazoles. Journal of Medicinal Chemistry, 41, 1242-1251. http://dx.doi.org/10.1021/jm970545c

[11] Dreyer, C. and Hausen, P. (1978) Inhibition of Mammalian RNA Polymerase by 5,6-Dichlororibofuranosylbenzimidazole (DRB) and DRB Triphosphate. Nucleic Acids Research, 5, 3325-3335. http://dx.doi.org/10.1093/nar/5.9.3325

[12] Porcari, A.R., Devivar, R.V., Kucera, L.S., Drach, J.C. and Townsend, L.B. (1998) Design, Synthesis, and Antiviral Evaluations of 1-(Substituted benzyl)-2-substituted-5,6-dichlorobenzimidazoles as Nonnucleoside Analogues of 2,5,6Trichloro-1-( $\beta$-d-ribofuranosyl)benzimidazole. Journal of Medicinal Chemistry, 41, 1252-1262. http://dx.doi.org/10.1021/jm970559i

[13] Erhardt, P.W. (1987) In Search of the Digitalis Replacement. Journal of Medicinal Chemistry, 30, 231-237. http://dx.doi.org/10.1021/jm00385a001

[14] Tomczuk, B.E., Taylor Jr., C.R., Moses, L.M., Sutherland, D.B., Lo, Y.S., Johnson, D.N., Kinnier, W.B. and Kilpatrick, B.F. (1991) 2-Phenyl-3H-imidazo[4,5-b]pyridine-3-acetamides as Non-Benzodiazepine Anticonvulsants and An- 
xiolytics. Journal of Medicinal Chemistry, 34, 2993-3006. http://dx.doi.org/10.1021/jm00114a007

[15] Spasov, A.A., Yozhitsa, I.N. and Bugaeva, L.I. (1999) Benzimidazole Derivatives: Spectrum of Pharmacological Activity and Toxicological Properties (A Review). Pharmaceutical Chemistry Journal, 33, 232-243. http://dx.doi.org/10.1007/bf02510042

[16] Gravatt, G.L., Baguley, B.C., Wilson, W.R. and Denny, W.A. (1994) DNA-Directed Alkylating Agents. 6. Synthesis and Antitumor Activity of DNA Minor Groove-Targeted Aniline Mustard Analogs of Pibenzimol (Hoechst 33258). Journal of Medicinal Chemistry, 37, 4338-4345. http://dx.doi.org/10.1021/jm00051a010

[17] Horton, D.A., Bourne, G.T. and Smythe, M.L. (2003) The Combinatorial Synthesis of Bicyclic Privileged Structures or Privileged Substructures. Chemical Reviews, 103, 893-930. http://dx.doi.org/10.1021/cr020033s

[18] Kim, J.S., Gatto, B., Yu, C., Liu, A., Liu, L.F. and La Voie, E.J. (1996) Substituted 2,5’-Bi-1H-benzimidazoles: Topoisomerase I Inhibition and Cytotoxicity. Journal of Medicinal Chemistry, 39, 992-998. http://dx.doi.org/10.1021/jm950412w

[19] Lu, J., Yang, B. and Bai, Y. (2002) Microwave Irradiation Synthesis of 2-Substituted Benzimidazoles Using PPA as a Catalyst under Solvent-Free Conditions. Synthetic Communications, 32, 3703-3709. http://dx.doi.org/10.1081/SCC-120015381

[20] Geratz, J.D., Stevens, F.M., Polakoski, K.L. and Parrish, R.F. (1979) Amidino-Substituted Aromatic Heterocycles as Probes of the Specificity Pocket of Trypsin-Like Proteases. Archives of Biochemistry and Biophysics, 197, 551-559. http://dx.doi.org/10.1016/0003-9861(79)90279-0

[21] Tidwell, R.R., Geratz., J.D., Dann, O., Volz, G., Zeh, D. and Loewe, H. (1978) Diarylamidine Derivatives with One or Both of the Aryl Moieties Consisting of an Indole or Indole-Like Ring. Inhibitors of Arginine-Specific Esteroproteases. Journal of Medicinal Chemistry, 21, 613-623. http://dx.doi.org/10.1021/jm00205a005

[22] Fairley, T.A., Tidwell, R.R., Donkor, I., Naiman, N.A., Ohemeng, K.A., Lombardy, R.J., Bentley, J.A. and Cory, M. (1993) Structure, DNA Minor Groove Binding, and Base Pair Specificity of Alkyl- and Aryl-Linked Bis(amidinobenzimidazoles) and Bis(amidinoindoles). Journal of Medicinal Chemistry, 36, 1746-1753. http://dx.doi.org/10.1021/jm00064a008

[23] Riadi, Y., Mamouni, R., Azzalou, R., EI Haddad, M., Routier, S., Guillaumet, G. and Lazar, S. (2011) An Efficient and Reusable Heterogeneous Catalyst Animal Bone Meal for Facile Synthesis of Benzimidazoles, Benzoxazoles, and Benzothiazoles. Tetrahedron Letters, 52, 3492-3495. http://dx.doi.org/10.1016/j.tetlet.2011.04.121

[24] Bachhav, H.M., Bhagat, S.B. and Telvekar, V.N. (2011) Efficient Protocol for the Synthesis of Quinoxaline, Benzoxazole and Benzimidazole Derivatives Using Glycerol as Green Solvent. Tetrahedron Letters, 52, 5697-5701. http://dx.doi.org/10.1016/j.tetlet.2011.08.105

[25] Blacker, A.J., Farah, M.M., Hall, M.I. Marsden, S.P, Saidi, O. and Williams, J.M. (2009) Synthesis of Benzazoles by Hydrogen-Transfer Catalysis. Organic Letters, 11, 2039-2042. http://dx.doi.org/10.1021/ol900557u

[26] Patil, V.D., Patil, J., Rege, P. and Dere, G. (2011) Mild and Efficient Synthesis of Benzimidazole Using Lead Peroxide Under Solvent-Free Conditions. Synthetic Communications, 41, 58-62. http://dx.doi.org/10.1080/00397910903531789

[27] Saha, P., Ramana, T., Purkait, N., Ashif, A.M., Paul, R. and Punniyamurthy, T. (2009) Ligand-Free Copper-Catalyzed Synthesis of Substituted Benzimidazoles, 2-Aminobenzimidazoles, 2-Aminobenzothiazoles, and Benzoxazoles. Journal of Organic Chemistry, 74, 8719-8725. http://dx.doi.org/10.1021/j0901813g

[28] Evindar, G. and Batey, R.A. (2006) Parallel Synthesis of a Library of Benzoxazoles and Benzothiazoles Using LigandAccelerated Copper-Catalyzed Cyclizations of Ortho-Halobenzanilides. Journal of Organic Chemistry, 71, 1802-1808. http://dx.doi.org/10.1021/jo051927q

[29] Yang, D., Fu, H., Hu, L., Jiang, Y. and Zhao, Y. (2008) Copper-Catalyzed Synthesis of Benzimidazoles via Cascade Reactions of $O$-Haloacetanilide Derivatives with Amidine Hydrochlorides. Journal of Organic Chemistry, 73, 78417844. http://dx.doi.org/10.1021/jo8014984

[30] Kamila, S., Koh, B. and Biehl, E.R. (2006) Microwave-Assisted “Green” Synthesis of 2-Alkyl/Arylbenzothiazoles in One Pot: A Facile Approach to Anti-Tumor Drugs. Journal of Heterocyclic Chemistry, 43, 1609-1612. http://dx.doi.org/10.1002/jhet.5570430627

[31] Kamila, S., Zhang, H. and Biehl, E.R. (2005) One-Pot Synthesis of 2-Aryl- and 2-Alkylbenzothiazoles under Microwave Irradiation. Heterocycles, 65, 2119-2126. http://dx.doi.org/10.3987/COM-05-10466

[32] Cai, L., Ji, X., Yao, Z., Xu, F. and Shen, Q. (2011) Efficient Synthesis of Functionalized Benzimidazoles and Perimidines: Ytterbium Chloride Catalyzed C-C Bond Cleavage. Chinese Journal of Chemistry, 29, 1880-1886. http://dx.doi.org/10.1002/cjoc.201180328

[33] Wang, Z.-X. and Qin, H.-L. (2005) Reaction of 1,3-Dicarbonyl Compounds with o-Phenylenediamine or 3,3'-Diami nobenzidine in Water or under Solvent-Free Conditions via Microwave Irradiation. Journal of Heterocyclic Chemistry, 42, 1001-1005. http://dx.doi.org/10.1002/jhet.5570420540 
[34] Yu, C., Guo, P., Jin, C. and Su, W. (2009) The Synthesis of Benzimidazole Derivatives in the Absence of Solvent and Catalys. Journal of Chemical Research, 5, 333-336.

[35] Itoh, K., Ishida, H. and Chikashita, H. (1982) The Reactions of Benzylidenmalononitriles $\beta$-Nitrostyrenes with $o$-Phenylenediamine including the New Organic Redox Reactions between the Olefins and 2-Phenylbenzimidazolines. Chemistry Letters, 1117-1118. http://dx.doi.org/10.1246/cl.1982.1117

[36] Li, J., Benard, S., Neuville, L. and Zhu, J. (2012) Copper Catalyzed N-Arylation of Amidines with Aryl Boronic Acids and One-Pot Synthesis of Benzimidazoles by a Chan-Lam-Evans $N$-Arylation and C-H Activation/C-N Bond Forming Process. Organic Letters, 14, 5980-5983. http://dx.doi.org/10.1021/ol3028847

[37] Chari, M.A., Shobha, D., Kenawy, E.R., Al-Deyab, S.S., Subba Reddy, B.V. and Vinu, A. (2010) Nanoporous Aluminosilicate Catalyst with 3D Cage-Type Porous Structure as an Efficient Catalyst for the Synthesis of Benzimidazole Derivatives. Tetrahedron Letters, 51, 5195-5199. http://dx.doi.org/10.1016/j.tetlet.2010.07.132

[38] Lei, M., Ma, L. and Hu, L. (2012) One-Pot Synthesis of $1 H$-Benzimidazole Derivatives Using Thiamine Hydrochloride as a Reusable Organocatalyst. Synthetic Communications, 42, 2981-2993. http://dx.doi.org/10.1080/00397911.2011.573610

[39] Rostamizadeh, S., Aryan, R. and Ghaieni, H.R. (2011) Aqueous 1 M Glucose Solution as a Novel and Fully Green Reaction Medium and Catalyst for the Oxidant-Free Synthesis of 2-Arylbenzimidazoles. Synthetic Communications, 41, 1794-1804. http://dx.doi.org/10.1080/00397911.2010.492460

[40] Saha, D., Saha, A. and Ranu, B.C. (2009) Remarkable Influence of Substituent in Ionic Liquid in Control of Reaction: Simple, Efficient and Hazardous Organic Solvent Free Procedure for the Synthesis of 2-Aryl Benzimidazoles Promoted by Ionic Liquid, [pmim]BF 4 . Green Chemistry, 11, 733-737. http://dx.doi.org/10.1039/b823543k

[41] Heravi, M.M., Tajbakhsh, M., Ahmadi, A.N. and Mohajerani, B. (2006) Zeolites. Efficient and Eco-Friendly Catalysts for the Synthesis of Benzimidazoles. Monatshefte fur Chemie, 137, 175-179.

[42] Cohen, V.I. (1979) A New Method of Synthesis of Some 2-Aryl and 2-Heterocyclic Benzimidazole, Benzoxazole and Benzothiazole Derivatives. Journal of Heterocyclic Chemistry, 16, 13-16. http://dx.doi.org/10.1002/jhet.5570160103

[43] Lam, T., Hilgers, M.T., Cunningham, M.L., Kwan, B.P., Nelson, K.J., Brown-Driver, V., Ong, V., Trzoos, M., Hough, G., Joy Shaw, K. and Finn, J. (2014) Structure-Based Design of New Dihydrofolate Reductase Antibacterial Agents: 7-(Benzimidazol-1-yl)-2,4-diaminoquinazolines. Journal of Medicinal Chemistry, 57, 651-668. http://dx.doi.org/10.1021/jm401204g 